\title{
Keanekaragaman Jenis Kupu-kupu Familia Nymphalidae dan Pieridae di Kawasan Cirengganis dan Padang Rumput Cikamal Cagar Alam Pananjung Pangandaran
}

\author{
Virda Catur Lestari, Tatang S. Erawan, Melanie, Hikmat Kasmara dan Wawan \\ Hermawan* \\ Departemen Biologi, Fakultas Matematika dan Ilmu Pengetahuan Alam, \\ Universitas Padjadjaran \\ •Alamat korespodensi: wawan.hermawan@unpad.ac.id
}

\begin{abstract}
The diversity of butterflies' family of Nymphalidae and Pieridae at Cirengganis area and Cikamal Savannah area of Pananjung Sanctuary of Pangandaran
\end{abstract}

The research reported the diversity o.f butterflies of Nymphalidae and Pieridae Families at Cirengganis area and Cikamal Savannah area which located at Pananjung Sanctuary, Pangandaran. The experiment was conducted using visual encounter survey method. The butterflies were caught using sweeping technique. The butterflies were collected and identified. Abiotic factors such light intensity and temperature were measured during observation. The result showed that 13 species of nymphalidae family were identified whilst only 2 species were identified belongs to the family of Pieridae. Butterfly diversity index at Cirengganis and Cikamal Savannah categorized as moderate with value of 2.285647. Vegetation that interacted with the butterflies were Tectona grandis), Psychotria aurantiaca, and Melastoma malabathricum. Furthermore, light intensity and temperature at Cirengganis were detected at 12473.33 lux and $28.6^{\circ} \mathrm{C}$, respectively. While at Cikamal Savannah, the light intensity was measured at 26900 lux and temperature reached $33.6^{\circ} \mathrm{C}$.

Keywords: Visual encounter survey, Abiotic factor, Vegetation

\begin{abstract}
ABSTRAK
Penelitian ini melaporkan mengenai keanekaragaman Jenis Kupu-Kupu Famili Nymphalidae dan Pieridae di kawasan Cirengganis dan Padang Rumput Cikamal Cagar Alam Pananjung Pangandaran. Metode yang digunakan adalah metode Visual Encounter Survey (VES). Penangkapan kupu-kupu dilakukan dengan teknik sweeping. Kupu-kupu yang diperoleh dikoleksi dan diidentifikasi. Faktor abiotik seperti intensitas cahaya dan suhu diukur selama pengamatan. Serta diamati pula vegetasi sekitar lokasi pengamatan yang berinteraksi dengan kupu-kupu. Hasil pengamatan diperoleh total kupu-kupu famili Nymphalidae sebanyak 13 spesies dan kupu-kupu famili Pieridae sebanyak 2 spesies. Nilai indeks keanekaragaman kupu-kupu di kawasan Cirengganis dan Padang Rumput Cikamal tergolong kategori sedang yaitu 2,285647. Hasil vegetasi yang diketahui berinteraksi dengan kupu-kupu yaitu jati (Tectona grandis), ki kores (Psychotria aurantiaca), dan harendong (Melastoma malabathricum). Sementara rata-rata intensitas cahaya dan suhu di Cirengganis sebesar 12473,33 lux dan 28,6 ${ }^{\circ} \mathrm{C}$ dan di Padang Rumput Cikamal sebesar 26900 lux dan $33,6^{\circ} \mathrm{C}$.
\end{abstract}

Kata Kunci: Visual Encounter Survey, Faktor abiotik, Vegetasi 


\section{PENDAHULUAN}

Taman Wisata Cagar Alam Pananjung Pangandaran, Jawa Barat merupakan salah satu kawasan konservasi di Indonesia yang memiliki potensi keanekaragaman hayati yang cukup tinggi baik flora, fauna maupun ekosistemnya. Salah satu keanekaragaman hayati yang terdapat di Taman Wisata Cagar Alam Pananjung Pangandaran yaitu keanekaan jenis kupu-kupu.

Kupu-kupu merupakan bagian dari keanekaragaman hayati yang harus dijaga kelestariannya. Kupu-kupu memiliki nilai penting bagi manusia maupun lingkungan antara lain, nilai ekonomi, ekologi, estetika, pendidikan, konservasi dan budaya (Lamatoa dkk, 2013 ). Dari perkiraan 17.500 jenis kupu-kupu di dunia, tak kurang dari 1.600 jenis diantaranya tersebar di Indonesia. Keadaan alam Indonesia dengan iklim tropik menjadi habitat yang cocok bagi perkembangan berbagai spesies kupu-kupu, yang diperkirakan sekitar 4.000-5.000 spesies, namun sampai saat ini baru sekitar setengahnya yang sudah diketahui spesiesnya (Arrummaisha dkk, 2014).

Famili Nymphalidae meliputi kupu-kupu berukuran kecil hingga sedang $(25-100 \mathrm{~mm})$, ciri khas pada Nymphalidae ialah pasangan tungkai depan yang mengecil (kecuali pada kupu-kupu betina Libytheinae) (Landman, 2001). Kupu-kupu anggota dari famili ini umumnya berwarna cokelat, oranye, kuning, dan hitam. Kupu-kupu famili ini merupakan kelompok yang paling beragam jenisnya dengan variasi dan pola bentuk sayap. Kupu-kupu jantan biasanya memiliki pasangan tungkai depan tertutup oleh kumpulan sisik yang padat menyerupai sikat, sehingga kupu-kupu ini juga dikenal sebagai kupu- kupu berkaki sikat (Peggie \& Amir, 2006).

Famili Pieridae meliputi kupu-kupu berukuran kecil hingga sedang (25- $100 \mathrm{~mm}$ ), memiliki tiga pasang kaki, sayap tidak berekor, dan biasanya berwarna putih atau kuning dengan sel sayap belakang yang tertutup. Famili ini dapat terbang jauh (beberapa spesies mempunyai sifat migrasi) dan sering ditemukan dalam jumlah banyak di sekeliling air (Sihombing, 1999).

Keanekaragaman hayati harus dijaga dari kerusakan habitat dan kepunahan maupun penurunan keanekaan jenis hayatinya. Seperti satwa lainnya, kupu-kupu juga mengalami ancaman kelangkaan jika tidak dilakukan perlindungan, pelestarian serta pembinaan habitat agar tetap lestari. Oleh karena itu dalam upaya konservasi keanekaragaman hayati, maka dilakukan penelitian mengenai keanekaan jenis kupu-kupu di kawasan Taman Wisata Cagar Alam Pananjung Pangandaran, Jawa Barat.

\section{BAHAN DAN METODE}

Alat yang digunakan dalam pengamatan ini antara lain yaitu alat tulis, buku panduan identifikasi atau field guide, GPS, insect net, jarum pentul, kamera, kertas papilot, label, luxmeter, papan perentang, termometer, worksheet. Bahan -bahan yang digunakan dalam pengamatan ini diantaranya yaitu alkohol 70\%, dan kapur barus/kamper.

Pengamatan ini dilakukan dengan metode jelajah dengan cara menyusuri jalan setapak sekitar kawasan Cirengganis dan Padang Rumput Cikamal Taman Wisata Cagar Alam Pananjung Pangandaran, Jawa Barat. Penangkapan kupu-kupu dilakukan dengan menggunakan insect net dengan teknik sweeping. Metode yang digunakan adalah Visual Encounter Survey (VES) atau Survei Penjumpaan Langsung. Pengamatan dilakukan sepanjang jalur transek bayangan yaitu dengan jarak $\pm 1000 \mathrm{~m}$ yang dibagi ke dalam 10 titik sampling $(100 \mathrm{~m} / \mathrm{titik}) \mathrm{di}$ lokasi sekitar kawasan Cirengganis dan Padang Rumput Cikamal Cagar Alam Pananjung Pangandaran. Metode Visual Encounter Survey (VES) dilakukan pada titik sampling yang telah ditentukan, kemudian mencatat penjumpaan dengan kupu-kupu, parameter yang diukur yaitu jenis, jumlah, waktu, dan aktivitas (Wahyuni dkk, 2014).

Pengamatan dilakukan pada pagi hari pukul 08.00 - 12.00 WIB dan sore hari pukul $14.00-16.00$ WIB. Pengukuran data abiotik suhu $\left({ }^{\circ} \mathrm{C}\right)$ dan intensitas cahaya serta pencatatan data biotik berupa vegetasi tumbuhan di lokasi pengamatan selama pengamatan. Sampel yang akan dikoleksi hanya satu spesimen setiap spesies. Apabila saat pengambilan sampel menemukan individu kupu-kupu pada jenis yang sama, maka cukup dihitung jumlahnya serta dicatat ciri-cirinya dan kupu-kupu tersebut akan dilepaskan kembali. Sampel kupu-kupu yang telah ditangkap akan disimpan dalam kertas papilot yang sudah diberi keterangan nomor, serta dicatat ciricirinya pada worksheet. Kemudian kupu-kupu diawetkan untuk dijadikan spesimen dengan menyuntikkan alkohol 70\% dibagian mesothoraks secara tegak lurus. Sayap kupu-kupu direntangkan pada papan perentang agar sayap merentang sempurna. Tahap selanjutnya kupu-kupu diletakkan diatas sterofoam dengan ditusuk menggunakan jarum pentul, sayap kupu-kupu dijepit dengan potongan kertas minyak yang ditahan menggunakan 
jarum pentul yang ditancapkan di atas papan perentang. Perentangan sayap kupu-kupu dilakukan dengan menggunakan pinset agar sayap kupu-kupu tidak rusak. Beri label jenis dan keterangan spesies pada tiap spesimen. Identifikasi spesimen yang telah didapatkan menggunakan buku panduan identifikasi field guide Practical Guide to the Butterflies of Bogor Botanic Garden (Peggie \& Amir, 2006) dan Identification Guide for Butterflies of West Java (Schulze, 2005). Penyimpanan kupu-kupu dilakukan dalam kotak spesimen yang telah diberi kapur barus/kamper sebagai pengawet dan menghindarkan spesimen dari semut atau jamur.

Hasil data yang diperoleh, dianalisis menggunakan indeks dominansi, indeks kekayaan jenis Margalef, indeks keanekaragaman ShannonWiener, dan indeks kemerataan.

\section{a. Indeks Dominansi Jenis (D)}

Dominansi jenis kupu- kupu dihitung menggunakan indeks dominansi Simpson (D) dengan rumus: (Odum,1993).

Keterangan :

$$
D=\frac{n i}{N} x 100 \%
$$

D : Indeks Dominansi

ni : Jumlah Individu Suatu Jenis

$\mathrm{N}$ : Jumlah Individu Seluruh Jenis

b. Indeks Kekayaan Margalef (Dmg)

$$
D m g=\frac{\mathbf{s}-\mathbf{1}}{\ln (\boldsymbol{S})}
$$

Keterangan :

Dmg : Indeks Kekayaan Margalef

S: Jumlah Jenis yang ditemukan

$\mathrm{N}$ : Jumlah Individu Seluruh Jenis

c. Indeks Keanekaragaman Shannon-Wiener $\left(\mathrm{H}^{\prime}\right)$

$$
\begin{gathered}
H^{\prime}=-\sum p i \ln p i \\
p i=\frac{\mathbf{n i}}{\mathbf{N}}
\end{gathered}
$$

Keterangan :

$\mathrm{H}^{\prime}$ :Indeks Keanekaragaman Shannon-Wiener $\mathrm{Pi}=\mathrm{ni} / \mathrm{N}$

ni: Jumlah Individu Jenis ke-i

$\mathrm{N}$ :Jumlah Individu Seluruh Jenis (Odum, 1993).

\section{d. Indeks Kemerataan (E)}

$$
E=\frac{\mathrm{H}^{\prime}}{\ln (S)}
$$

Keterangan :

$\mathrm{E}:$ Indeks kemerataan jenis

$\mathrm{H}^{\prime}$ : Indeks keanekaragaman Shannon-Wiener

$S$ : Jumlah jenis yang ditemukan Indeks ini menunjukkan pola sebaran satwa, yaitu merata atau tidak (Wahyuni dkk,2014).

\section{e. Persebaran (Frekuensi)}

Analisis data frekuensi merupakan penentuan besarnya jumlah presentase setiap spesies pada masing-masing plot. Frekuensi relatif merupakan persentase kehadiran suatu individu dalam sejumlah titik sampling (Odum, 1993).

Frekuensi Mutlak $(\mathrm{FM})=\frac{\sum \text { plot ditemukan spesies A }}{\sum \text { seluruh plot }}$

Frekuensi Relatif $(F R)=\frac{\text { FM Spesies A }}{\sum \text { FM Seluruh Spesies }} \times 100 \%$

Keterangan :

FR : Frekuensi Relatif

FM: Frekuensi Mutlak (jumlah individu tiap jenis yang menempati plot

\section{HASIL DAN PEMBAHASAN}

Dari hasil pengamatan pada kedua lokasi, kupu-kupu famili Nymphalidae dan Pieridae yang ditemukan berjumlah 15 jenis dari 7 subfamili, yaitu dapat dilihat pada Gambar 1 dan 2. Berdasarkan hasil pengamatan yang telah dilakukan pada seluruh spesies kupu-kupu yang diperoleh, menunjukkan bahwa kupu-kupu dari famili Nymphalidae paling banyak ditemukan pada kedua lokasi pengamatan. Hal ini dikarenakan famili Nymphalidae memiliki jumlah spesies yang relatif banyak. Selain memiliki anggota terbanyak, tingginya populasi kupu-kupu dari famili Nymphalidae pada lokasi pengamatan juga dikarenakan adanya vegetasi yang sesuai untuk keberlangsungan hidup kupu-kupu tersebut seperti terdapatnya tumbuhan inang dan tumbuhan pakan kupu-kupu, baik sebagai sumber makanan maupun sebagai tempat berlindung.
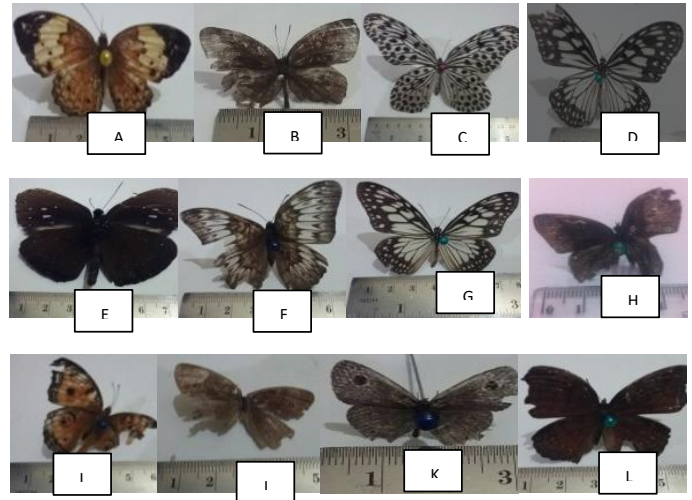

Gambar 1. Jenis Kupu-kupu Famili Nymphalidae yang ditemukan. (A) Cupha erymanthis, (B) Mycalesis sudra sudra, (C) Idea stoli stoli, (D) Tanaecia Limniace conjuncta, (E) Euploea midamus rafflesi, (F) Tanaecia palguna, (G) Ideopsis juventa, (H) Mycalesis horsfieldii, (I) Junonia almana, (J) Ypthima philomela (K) Junonia hedonia ida, (L) Junonia atlites. 


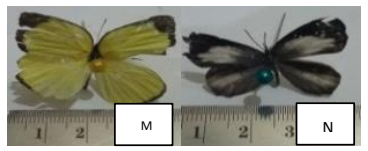

Gambar 2. Jenis Kupu-kupu Famili Pieridae yang ditemukan. (M) Eurema blanda blanda,(N) Appias sp.

Kupu-kupu memilih tumbuhan sebagai pakan, hinggap maupun inang berdasarkan interaksi antara kupu-kupu pada tumbuhan begitu pula sebaliknya. Kupu-kupu akan tertarik mendatangi bunga sebagai sumber nektar atau makanannya berdasarkan tiga karakteristik yaitu bentuk bunga, warna, dan aroma (Arrummaisha dkk, 2014).

Spesies kupu-kupu dari famili Nymphalidae yang paling banyak ditemukan yaitu jenis Cupha erymanthis. Pada kedua lokasi pengamatan spesies ini ditemukan berjumlah 16 individu. Cupha erymanthis saat ditangkap sedang hinggap di tumbuhan kirinyuh (Eupatorium odoratum) dari famili Asteraceae. Menurut Peggie \& Amir (2006), kupu-kupu jenis ini umumnya dijumpai di hutan dataran rendah, dan food plant kupu-kupu jenis ini yaitu dari famili Flacourtiaceae dan Asteraceae. Nilai indeks dominansi dapat dilihat pada Tabel 1 dan Tabel 2. Kupu-kupu jenis Cupha erymanthis dari famili Nymphalidae pada kedua lokasi relatif tinggi yaitu sebesar $74 \%$. Sedangkan spesies kupu-kupu dari famili Pieridae yang mendominansi yaitu Eurema blanda. Nilai indeks dominansi spesies Eurema blanda pada lokasi pengamatan relatif tinggi yaitu sebesar 71\%. Menurut Brower et al.(1998), apabila nilai indeks dominansi $<0,5$ menunjukkan tidak ada organisme yang mendominansi.

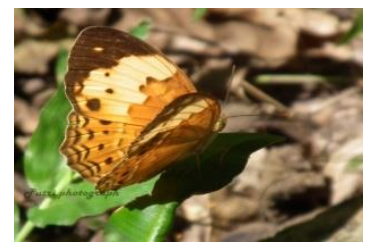

Gambar 3. Kupu-kupu jenis Cupha erymanthis (Biodiversity Wariors, 2014).

Tabel 1. Hasil analisis indeks dominansi, indeks kekayaan, indeks keanekaragaman, dan indeks kemerataan kupu-kupu famili Nymphalidae dan Pieridae di kawasan Cirengganis.

\begin{tabular}{|c|c|c|c|c|c|}
\hline Nama Jenis & Jumlah Individu & $\mathrm{D}(\%)$ & Dmg & $\mathrm{H}^{\prime}$ & $\mathrm{E}$ \\
\hline \multicolumn{6}{|l|}{ Famili Nymphalidae } \\
\hline Cupha erymanthis & 10 & $34 \%$ & & & \\
\hline Mycalesis sudra sudra & 1 & $3 \%$ & & & \\
\hline Junonia atlites & 1 & $3 \%$ & & & \\
\hline Ides stoli stoli & 2 & $7 \%$ & & & \\
\hline \multicolumn{6}{|l|}{ Tanaecia Limniace } \\
\hline conjuncta & 7 & $24 \%$ & & & \\
\hline Euplea midamus rafflesi & 2 & $7 \%$ & & & \\
\hline Mycalesis horsfieldii & 2 & $7 \%$ & & & \\
\hline Ideopsis juventa & 4 & $14 \%$ & & & \\
\hline Jumlah & 29 & $100 \%$ & 2,07881943 & 1,768976 & 0,850697511 \\
\hline \multicolumn{6}{|l|}{ Famili Pieridae } \\
\hline Eurema blanda & 2 & $100 \%$ & 0 & & 0 \\
\hline Jumlah & 2 & $100 \%$ & 0 & 0 & 0 \\
\hline
\end{tabular}

Berdasarkan hasil analisis pada Tabel 1 dan Tabel 2 diketahui bahwa nilai indeks kekayaan dari famili Nymphalidae lebih tinggi dibandingkan dengan famili Pieridae. Kekayaan merupakan nilai yang ukurannya dipengaruhi oleh banyaknya jenis dan jumlah individu pada suatu lokasi pengamatan. Semakin banyak jumlah jenis dan individu pada suatu lokasi maka nilai indeks kekayaan semakin tinggi (Syaputra, 2015).

Jumlah jenis kupu-kupu famili Nymphalidae di kedua lokasi pengamatan relatif banyak yaitu ada
13 jenis, sementara itu jumlah dari seluruh jenis yang ditemukan sebanyak 44 individu. Indeks kekayaan yang diperoleh famili Nymphalidae tergolong tinggi yaitu sebesar 4,2. Sedangkan indeks kekayaan yang diperoleh famili Pieridae tergolong kategori rendah yaitu sebesar 0,5 . Pada kedua lokasi pengamatan hanya ditemukan 2 jenis kupu-kupu dari famili Pieridae. Menurut Wahyuni dkk. (2014), kekayaan jenis menunjukkan perbandingan jumlah jenis yang ditemukan di suatu lokasi dengan jumlah dari masing-masing jenis yang ditemukan. 
Tabel 2. Hasil analisis indeks dominansi, indeks kekayaan, indeks keanekaragaman, dan indeks kemerataan kupu-kupu famili Nymphalidae dan Pieridae di kawasan Padang Rumput Cikamal.

\begin{tabular}{|c|c|c|c|c|c|}
\hline Nama Jenis & Jumlah Individu & $\mathrm{D}(\%)$ & Dmg & $\mathrm{H}^{\prime}$ & $\mathrm{E}$ \\
\hline \multicolumn{6}{|l|}{ Famili Nymphalidae } \\
\hline Idea stoli stoli & 1 & $7 \%$ & & & \\
\hline Junonia almana & 3 & $20 \%$ & & & \\
\hline Mycalesis mineus & 1 & $7 \%$ & & & \\
\hline Ypthima philomela & 1 & $7 \%$ & & & \\
\hline Tanaecia palguna & 1 & $7 \%$ & & & \\
\hline Junonia hedonia ida & 2 & $13 \%$ & & & \\
\hline Cupha erymanthis & 6 & $40 \%$ & & & \\
\hline Jumlah & 15 & $100 \%$ & 2,21561624 & 1,132151 & 0,581810707 \\
\hline \multicolumn{6}{|l|}{ Famili Pieridae } \\
\hline Eurema blanda blanda & 5 & $71 \%$ & & & \\
\hline Appias sp. & 2 & $29 \%$ & & & \\
\hline Jumlah & 7 & $100 \%$ & 0,51389834 & 0,598269 & 0,863120569 \\
\hline
\end{tabular}

Nilai indeks keanekaragaman jenis kupukupu tertinggi terdapat pada lokasi pengamatan Cirengganis, hal ini dikarenakan lokasi pengamatan sekitar kawasan Cirengganis merupakan daerah hutan yang memiliki vegetasi yang beragam, mulai dari rerumputan, semak belukar, hingga pepohonan. Ini memungkinkan kupu-kupu mempunyai ketersediaan sumber pakan yang melimpah. Keanekaragaman jenis bisa dijadikan patokan dalam menilai kekayaan alam hayati pada kawasan tertentu. Keanekaragaman jenis suatu komunitas tinggi jika komunitas itu disusun oleh banyak jenis. Sebaliknya suatu komunitas dikatakan memiliki keanekaragaman jenis yang rendah jika komunitas itu disusun oleh sedikit jenis dan hanya sedikit jenis yang dominan (Indriyanto, 2006 dalam Syaputra, 2015).

Berdasarkan indeks keanekaragaman Shannon-Wiener $\left(\mathrm{H}^{\prime}\right)$ yang terdapat pada Tabel 1 dan Tabel 2, pada lokasi Cirengganis jenis kupukupu dari famili Nymphalidae memperoleh nilai sebesar 1,8. Sedangkan pada famili Pieridae diperoleh nilai sebesar 0. Maka dapat diketahui bahwa keanekaragaman jenis kupu-kupu famili Nymphalidae di kawasan Cirengganis tergolong sedang dan keanekaragaman kupu-kupu famili Pieridae yang terdapat dikawasan ini sangat rendah. Sedangkan pada lokasi padang rumput Cikamal, kedua famili menunjukkan nilai yang sedang, terlihat dari hasil analisis indeks shannon-Wiener yang diperoleh yaitu sebesar 1,1 dan 0,591. Menurut
Fachrul (2012), indeks keanekaragaman tergolong sedang apabila menunjukkan nilai $1<\mathrm{H}^{\prime}<3$.

Perbedaan keanekaragaman spesies di kedua lokasi ini disebabkan karena kondisi lokasi antara Cirengganis dan Padang Rumput Cikamal berbeda. Cirengganis memiliki kanopi lebih tertutup dibandingkan dengan Padang Rumput Cikamal. Selain itu, jenis vegetasinya berupa tumbuhan berkayu yang memiliki tutupan pohon cukup rapat sehingga intensitas cahaya matahari yang masuk relatif sedikit. Sedangkan pada lokasi pengamatan Padang Rumput Cikamal banyak dijumpai tumbuhan penghasil nektar yaitu bunga Melastoma malabathricum sehingga banyak kupu-kupu yang hinggap untuk makan nektar pada bunga tersebut. Intensitas cahaya pada lokasi ini relatif tinggi, sebab kondisi lokasi pengamatan didominasi oleh rerumputan. Padang Rumput Cikamal merupakan daerah yang terbuka memiliki vegetasi yang sedikit, intensitas cahaya yang terlalu tinggi, serta kelembaban rendah Menurut Florida dkk.(2015), Kupu-kupu menyukai habitat dengan kelembaban yang tinggi karena dapat mengurangi dehidrasi atau resiko kekurangan air.

Selain itu, Handawa (2007) menyatakan bahwa luas wilayah yang dilalui dapat juga mempengaruhi tingkat keanekaragaman spesies kupu-kupu. Luas wilayah Cirengganis relatif lebih kecil dibandingkan dengan padang rumput cikamal. Sehingga pada lokasi Cirengganis lebih mudah untuk menemukan jenis kupu-kupu. Sedangkan pada 
wilayah Padang Rumput Cikamal lebih sulit menemukan spesies kupu-kupu karena memiliki luas kawasan lebih dari 3 Ha. Dewi dkk.(2016) menambahkan bahwa, semakin luas suatu kawasan maka jumlah individu juga akan semakin tinggi karena tersedianya banyak tempat untuk bernaung.

Namun, berdasarkan nilai indeks keanekaragaman Shannon-Wiener $\left(\mathrm{H}^{\prime}\right)$ famili Nymphalidae dan Pieridae pada kedua lokasi pengamatan, dapat dilihat pada tabel.3 menunjukkan hasil sebesar 2,285647. Maka diketahui bahwa keanekaragaman jenis kupu-kupu famili Nymphalidae dan Pieridae di kawasan Cirengganis dan Padang Rumput Cikamal tergolong sedang. Keanekaragaman yang sedang menunjukkan bahwa suatu komunitas memiliki kompleksitas yang sedang pada struktur habitat dan keragaman bentuk vegetasi, karena dalam komunitas itu tidak banyak terjadi interaksi antar jenis dibandingkan dengan komunitas yang sudah mencapai klimaks. Sehingga suatu komunitas yang sedang berkembang pada tingkat suksesi mempunyai jumlah jenis rendah dari pada komunitas yang sudah mencapai klimaks. Keanekaragaman jenis serangga berkorelasi dengan kompleknya penyusun struktural suatu habitat dan keragaman bentuk vegetasi (Dewi dkk, 2016).

Nilai indeks kemerataan (E) kupu-kupu (Tabel 1 dan Tabel 2) menunjukkan bahwa kupu- kupu famili Nymphalidae dan famili Pieridae di kawasan Cirengganis berkisar antara 0-0,8. Sedangkan kupu-kupu famili Nymphalidae dan famili Pieridae di lokasi pengamatan Padang Rumput Cikamal memperoleh hasil analisis indeks kemerataan sebesar 0,5-0,9. Hal ini meninjukkan bahwa di kawasan cirengganis tingkat kemerataan rendah sampai sedang, sedangkan di kawasan Padang Rumput Cikamal tingkat kemerataannya tinggi. Brower et al.(1998) berpendapat bahwa, apabila nilai kemerataan $<0,4$ menunjukkan tingkat kemerataan yang rendah, nilai kemerataan antara 0,4 - 0,6 menunjukkan tingkat kemerataan yang sedang, dan nilai kemerataan >0,6 menunjukkan tingkat kemerataan yang tinggi. Fachrul (2012) menambahkan, nilai kemerataan yang tinggi menunjukkan bahwa jumlah individu masingmasing spesies pada lokasi penelitian tersebut relatif sama, tidak ada spesies yang sangat menonjol. Namun, kemerataan jenis akan tergolong rendah apabila niai $E \approx 0$. Kemerataan jenis menunjukkan komposisi jumlah individu per jenis dalam suatu habitat tertentu. Semakin merata suatu persebaran satwa di suatu lokasi tertentu maka semakin baik pula kondisi lingkungan tersebut sehingga mampu mendukung kelangsungan hidup spesies tersebut.

Tabel 4. Hasil pengukuran intensitas cahaya dan suhu lokasi pengamatan.

\begin{tabular}{ccccc}
\hline \multirow{2}{*}{ Hari ke- } & \multicolumn{2}{c}{ Cirengganis } & \multicolumn{2}{c}{ Padang Rumput Cikamal } \\
\cline { 2 - 5 } & $\begin{array}{c}\text { Intensitas } \\
\text { Cahaya }(\mathrm{lux})\end{array}$ & Suhu $\left({ }^{\circ} \mathrm{C}\right)$ & $\begin{array}{c}\text { Intensitas } \\
\text { Cahaya }(\text { lux })\end{array}$ & Suhu $\left({ }^{\circ} \mathrm{C}\right)$ \\
\hline 1 & 8980 & 28,8 & 17300 & 33,4 \\
\hline 2 & 8980 & 28,8 & 31700 & 36,4 \\
\hline 3 & 19460 & 28,2 & 31700 & 31,1 \\
\hline Rata-rata & 12473,33 & 28,6 & 26900 & 3333
\end{tabular}

Pengukuran data abiotik dilakukan pada saat pengamatan, rata-rata intensitas cahaya dan suhu udara di kawasan Cirengganis dapat dilihat pada Tabel 4, memiliki nilai yang rendah yaitu 12473,33 lux dan $28,6^{\circ} \mathrm{C}$. Hal ini dikarenakan pada lokasi tersebut didominasi oleh tumbuhan tinggi yaitu pepohonan. Sehingga tutupan kanopi sangat rapat. Sedangkan di sekitar kawasan Padang Rumput Cikamal, intensitas cahaya dan suhu udara relatif tinggi yaitu sebesar 26900 lux dan $33,63{ }^{\circ} \mathrm{C}$.

Intensitas cahaya sangat berpengaruh terhadap keanekaragaman kupu-kupu di suatu lokasi pengamatan, kupu-kupu yang terdapat di kawasan
Cirengganis relatif lebih beragam jenisnya dibandingkan dengan kupu-kupu yang terdapat di kawasan Padang Rumput Cikamal. Hal ini dikarenakan kawasan Cirengganis memiliki intensitas cahaya yang relatif lebih rendah. Akan tetapi menurut Peggie \& Amir (2006 kupu-kupu umumnya dijumpai pada hari yang cerah dan tempat yang terbuka. Di dalam lokasi pengamatan Cirengganis, walaupun intensitas cahaya nya lebih rendah dibandingkan dengan padang rumput cikamal, namun keanekaragaman spesies kupu-kupu dan kekayaan kupu-kupu nya lebih tinggi. Hal ini 
dikarenakan oleh tumbuhan inang yang banyak tumbuh di kawasan ini.

Faktor intensitas cahaya juga mempengaruhi aktivitas kupu-kupu. Sebelum memulai aktivitas mencari makan, biasanya kupukupu merentangkan sayapnya dan berjemur untuk mengeringkan sayap di atas pucuk daun atau tanah. Connor et al. (2003) menjelaskan bahwa kupu-kupu berjemur di bawah sinar matahari untuk menghangatkan tubuh sebelum terbang, dimana sayap mereka menyerap sinar matahari.

Faktor lingkungan lainnya yang mempengaruhi keanekaragaman, persebaran serta aktivitas kupu-kupu yaitu suhu. Kupu-kupu merupakan hewan berdarah dingin (poikilotermik) yang aktivitasnya sangat dipengaruhi oleh termperatur lingkungannya (Sihombing, 1999). Pengukuran suhu di sekitar lokasi pengamatan Cirengganis sebesar $23^{\circ} \mathrm{C}$, sedangkan suhu di sekitar kawasan Padang Rumput Cikamal sebesar $29^{\circ} \mathrm{C}$. suhu di kedua lokasi pengamatan merupakan suhu yang relatif optimum untuk aktivitas kupu-kupu. Menurut Akutsu et al. (2007), suhu akan mempengaruhi aktivitas, penyebaran, pertumbuhan dan perkembangbiakan serangga. Umumnya kupukupu lebih aktif pada suhu tinggi karena pada saat itulah metabolisme dalam tubuhnya meningkat, namun apabila pada suhu rendah aktivitasnya akan menurun karena metabolisme tubuhnya melambat.

Faktor biotik yang mempengaruhi kelimpahan dan persebaran kupu-kupu adalah tumbuhan yang menjadi tumbuhan inang (host plant) atau tumbuhan pakan (food plant) yang menyediakan nektar bagi kupu-kupu. Struktur vegetasi yang terdapat di lokasi pengamatan dapat mempengaruhi kelimpahan pada jenis kupu-kupu. Menurut Sharma \& Joshi (2009), kompleksitas struktural habitat dan keragaman bentuk vegetasi berkorelasi dengan keragaman spesies serangga.

Tumbuhan yang sering di hinggapi kupu kupu antara lain ki rinyuh (Eupatorium odoratum), bungur(Lagerstromia speciosa), babadotan (Ageratum conyzoides), waru laut (Hibiscus tiliaceus), jati (Tectona grandis), harendong (Melastoma malabathricum), saliara (Lantana camara), jukut barong (Mimosa pudica), dan alang-alang (Imperata cylindrica). Kebanyakan tumbuhan yang dihinggapi oleh kupu-kupu merupakan tumbuhan berbunga yang menghasilkan nektar sebagai pakan kupukupu. Effendi (2009) menyatakan bahwa kelimpahan kupu-kupu berhubungan dengan kelimpahan tumbuhan penghasil nektar yang menyediakan energi dan nutrisi bagi kupu-kupu, dan keragaman kupu-kupu tidak hanya dipengaruhi oleh keberadaan volume nektar, tetapi dipengaruhi juga oleh kekayaan tumbuhan nektar dan kandungan gulanya.

\section{SIMPULAN}

Berdasarkan hasil inventarisasi serta identifikasi keanekaragaman jenis kupu-kupu di sekitar kawasan Cirengganis dan Padang Rumput Cikamal, dapat diambil simpulan bahwa terdapat 15 jenis kupu-kupu famili Nymphalidae yaitu Cupha erymanthis, Mycalesis sudra sudra, Idea stoli stoli, Tanaecia Limniace conjuncta, Euploea midamus rafflesi, Tanaecia palguna, Ideopsis juventa, Mycalesis horsfieldii, Junonia almana, Ypthima philomela (Junonia hedonia ida, Junonia atlites, Mycalesis mineus dan 2 jenis dari famili Pieridae yaitu Eurema blanda blanda dan Appias sp. Serta kenakekaragaman jenis kupu-kupu di Taman Wisata Cagar Alam Pananjung Pangandaran, Jawa Barat pada saat pengamatan termasuk kategori relatif sedang.

\section{UCAPAN TERIMA KASIH}

Peneliti mengucapkan terima kasih kepada pihak BKSDA serta seluruh pengelola Taman Wisata Cagar Alam Pananjung Pangandaran, Jawa Barat dan Departemen Biologi FMIPA UNPAD yang telah membantu memfasilitasi penelitian ini. Penelitian ini terselanggara melalui kegiatan Kuliah Kerja Lapangan 2017 Biologi FMIPA UNPAD yang diselenggarakan pada bulan Mei 2017.

\section{DAFTAR PUSTAKA}

Akutsu, K, CV Khen, and MJ Toda. 2007. Assessment of higher insect taxa as bioindicatorsfor different logging-disturbance regimes inlowland tropical rain forest in Sabah, Malaysia. Ecol Res. 22: 542-550.

Arrummaisha, LD, SE Rahayu, dan Sulisetijono. 2014. Preferensi Kupu-Kupu Familia Nymphalidae dan Lycaenidae pada Tumbuhan di Wisata Air Terjun Coban Rais Kota Batu, Jawa Timur. Jurusan Biologi, Fakultas MIPA, Universitas Negeri Malang.

Biodiversity Wariors. 2014. Katalog kupu-kupu. [Online]. http://www.biodiversitywarriors.orgisikatalog.phpidk=675\&judul=Rustic-kupu- 
kupu-orange. (Di akses pada tanggal 22 Mei 2017 pukul 15.45 WIB).

Brower, JE, CHZ Jerrold, and EIN Von. 1998, Field and Laboratory Methods for General Ecology. Third Edition, USA. Wm. C. Brown Publisher. New York.

Connor EF, J Hafernik, J Levy, VL Moore, and JK Rickman. 2003. Insect conservation in an urban biodiversity hotspot: The San Francisco Bay Area. Journal of Insect Conservation 6(4): 247-259.

Dewi, B, A Hamidah, dan J Siburian. 2016. Keanekaragaman dan Kelimpahan Jenis Kupu-kupu (Lepidoptera; Rhopalocera) di Sekitar Kampus Pinang Masak Universitas Jambi. Biospecies. 9(2): 32-38.

Effendi, MA. 2009. Keragaman Kupu-Kupu (Lepidoptera : Ditrysia) di Kawasan "Hutan Koridor" Taman Nasional Gunung HalimunSalak Jawa Barat. Institut Pertanian Bogor. Bogor.

Fachrul, MF. 2012. Metode Sampling Bioekologi. PT Bumi Aksara. Jakarta.

Florida, M, TR Setyawati, dan AH Yanti. 2015. Inventarisasi jenis kupu-kupu pada Hutan Kerangas di Kawasan Cagar Alam Mandor Kabupaten Landak. Protobiont 4 (1) : 260265.

Handawa, Y. 2007. Pemetaan Kupu-kupu Nymphalidae di Kawasan Batutegi Tanggamus, Lampung. Skripsi. Sarjana Biologi Fakultas MIPA. Universitas Lampung. Bandar Lampung.

Lamatoa, DC, R Koneri, R Siahaan, dan PV Maabuat. 2013. Populasi kupu-kupu (Lepidoptera ) di
Pulau Mantehage, Sulawesi Utara. Jurnal Ilmiah Sains 13 (1) : 52-56.

Landman, W. 2001. The Complete Encyclopedia of Butterflies. Grange Books.

Odum, EP. 1993. Dasar-Dasar Ekologi Edisi Ketiga. Gadjah Mada University Press. Yogyakarta.

Peggie, D, dan M Amir. 2006. Practical Guide to the Butterflies of Bogor Botanic Garden. Bidang Zoologi Pusat Penelitian Biologi. LIPI. Bogor.

Schulze, CH. 2005. Identification guide for butterflies of West Java - Families Papilionidae, Pieridae and Nymphalidae.

Sharma, G, and PC Joshi. 2009. Diversity of butterflies (Lepidoptera: Insecta) from Dholbaha dam (Distt. Hoshiarpur) in Punjab Shivalik India. Biological Forum 1 (2): 11-14.

Sihombing, DTH. 1999. Satwa Harapan I Pengantar Ilmu dan Teknologi Budidaya. Pustaka Wirausaha Muda. Bogor.

Syaputra, M. 2015. Pengukuran keanekaragaman kupu-kupu (lepidoptera) dengan menggunakan metode time search. Media Bina Ilmiah 9(4).

Wahyuni, I, RK Tohir, Y Widyaningrum, U Prabawati, dan R Lydiasari. 2014. Keanekaragaman Jenis Herpetofauna Di Jalur Cikaweni Pusat Pendidikan Konservasi Alam Bodogol (Ppkab), Resort Bodogol, Taman Nasional Gunung Gede Pangrango. Departeman Konservasi Sumberdaya Hutan dan Ekowisata. Fakultas Kehutanan. Institut Pertanian Bogor. Bogor. 